according to the International Atomic Energy Agency (IAEA).

The United Nations' nuclear watchdog reported on 19 February that the country now has more than a tonne of low-enriched uranium. That is much more than the agency's November 2008 estimate of 660 kilograms, suggesting that earlier stocks were misreported. Much of the excess was discovered during the agency's annual inventory of materials at Iran's uranium-enrichment facility at Natanz.

To be used in weapons, uranium must be enriched to around $90 \%$ pure uranium-235. Iran has so far enriched its uranium to just $3.49 \%$, or reactor-grade, the IAEA says. A longer version of this story can be found at http://tinyurl.com/cn8snu.

\section{deCode gets marketing go-ahead in California}

Eight months after being targeted by California regulators with a cease and desist' letter, deCode Genetics, a biotech company based in Reykjavik, last week received the equivalent of the state's blessing: a clinical laboratory licence.

deCode's in-house laboratory has passed muster with state regulators, and the company can begin marketing genetic tests in California. Last June's letter threatened deCode with penalties of up to US $\$ 10,000$ a day for marketing to California residents (see Nature 453, 1148-1149; 2008).

Two other high-profile firms - 23andMe and Navigenics - that received the letter were granted licences in August.

Kári Stefánsson, deCode's chief executive, says that the firm is awaiting a similar licence from the state of New York.

\section{Forensic science badly lacking in the United States}

The US forensic-science system is fragmented, underfunded and poorly supported by research, according to a report issued by the US National Research Council on 18 February.

The judiciary system relies on forensic science to link evidence to a suspect, but only nuclear-DNA analysis has been shown to make such connections reliably, the report says. The government should create a federal agency to support research on forensic methods and establish ways to quantify uncertainty, says the council. Forensic-science practitioners should undergo mandatory certification, and laboratories should be separated from law-enforcement and prosecutors' offices.

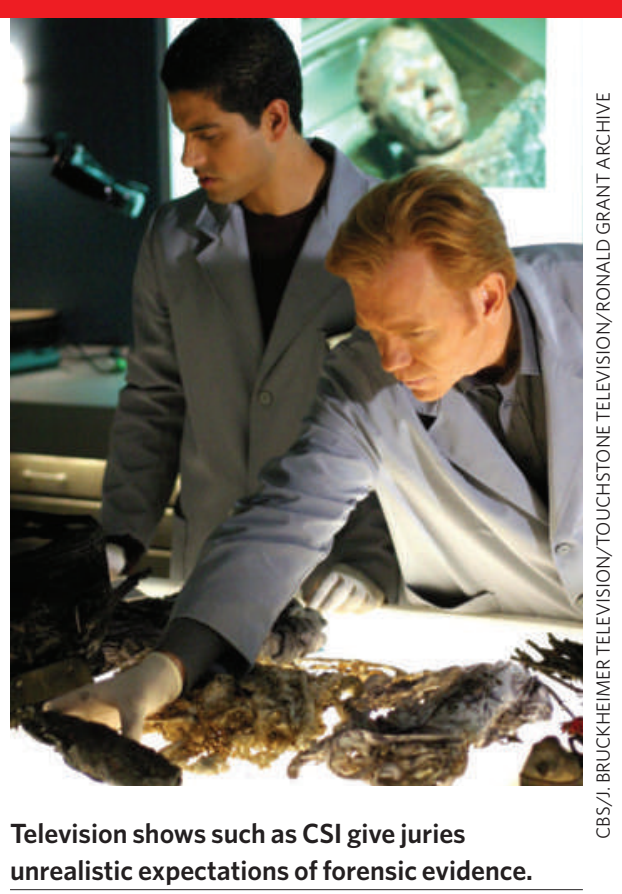

The US Senate judiciary committee will review the report and decide on the necessary hearings and legislation, a statement from chairman Patrick Leahy (Democrat, Vermont) says. Senator and ranking Republican of the committee Arlen Specter (Pennsylvania) says it is "incumbent on Congress to pursue the report's findings". 